\title{
NANOPARTICLES: A PROMISING DRUG DELIVERY APPROACH
}

\author{
RENU KADIAN* \\ Department of Pharmaceutical Sciences, PDM College of Pharmacy, Bahadurgarh, Jajjhar Haryana, India. Email: renukadian23@gmail.com
} Received: 16 August 2017, Revised and Accepted: 23 October 2017

\begin{abstract}
Nanoparticles are particles having a size range of 1 and 100 nanometers, defined as a small object behaving as a complete unit with respect to the drug transport and therapeutic properties. They have several advantages such as improvement in the intracellular infiltration, enhanced hydrophobic solubility, and circulation time of the drug. They reduce non-specific uptake and side effects of the conventional drug delivery systems. Nanoparticles offer more effective and convenient routes of administration (oral, pulmonary, parenteral, and transdermal) and used for drug delivery for treatment of cancer, diabetes, pain, asthma, allergy, infections, and so on. They allow targeted delivery and controlled release of the drug. Further research on their mechanism of action to meet better stability of nanoparticles in the biological system could be done.
\end{abstract}

Keywords: Nanoparticles, Drug delivery, Targeted delivery, Bioavailability, Stability.

(C) 2018 The Authors. Published by Innovare Academic Sciences Pvt Ltd. This is an open access article under the CC BY license (http://creativecommons. org/licenses/by/4. 0/) DOI: Http://dx.doi.org/10.22159/ajpcr.2018.v11i1.22035

\section{INTRODUCTION}

Nanoparticles are small object behaving as a whole entity with respect to its transport of drug to the target site with improved properties [1]. Nanoparticles have varied potential applications in pharmaceuticals, medical diagnostics, imaging, and therapeutic. Research on nanoparticles is of great benefit in surgeries and disease management by newer drug delivery approaches [2]. Nanoparticles are novel compounds which owing to their smallness have emerged as a new scientific field in medicines and technology over the past 10 years [3]. Unique physicochemical properties of nanoparticles are their ultra-smallness, greater surface area to mass ratio, and enhanced reactivity. These properties of nanoparticles help them to overcome the restrictions associated with traditional therapeutic and diagnostic agents [4]. Nanoparticles can integrate distinctive features that cannot be engineered into simple drugs and offer an exciting platform for drug delivery [5]. Nanoparticles are drug carriers with an improved capacity which provides greater stability to the drug entrapped inside it, leading to improved drug bioavailability and reduction in dosage frequency [6]. They could be considered a great candidate for future research on their stability and mechanism of action.

\section{ADVANTAGES OF NANOPARTICLES}

Nanoparticles are highly reactive species with unique physicochemical properties such as small controllable size and large surface to mass ratio [7]. They make the drug molecule more suitable for targeted drug delivery by improving their pharmacokinetic and pharmacodynamic properties [8]. Nanoparticles help in molecular targeted cancer therapy, recognition of cancer lesions, and determination of molecular signatures of the tumor by noninvasive imaging [9]. They have been considered an ideal choice for cancer therapy due to their ability to modify drug release from polymeric nanoparticles. They are also considered a good candidate for delivery of vaccines, contraceptives, and targeted antibiotics [10]. Nanoparticles permit more efficient drug use by protecting the drug in the systemic circulation and limiting admission of the drug to the selected sites. They also minimize unwanted side effects and deliver the drug at a controlled and sustained rate at the site of action [11] (Tables 1 and 2).

\section{PREPARATION OF NANOPARTICLES FROM PREFORMED POLYMERS (E.G., POLY [LACTIC ACID], POLY [CYANOACRYLATE], AND POLYSTYRENE)}

\section{Emulsion solvent evaporation method}

It is two step processes. In the first step, the polymer solution is emulsified into an aqueous phase, and in the second step, polymer solvent is evaporated, inducing polymer precipitation as nanoparticles which are collected by ultracentrifugation, washed with distilled water, and lyophilized for storage $[23,24]$.

\section{Double emulsion and evaporation method}

The aqueous drug solution is added to organic polymer solution with vigorous stirring to form $\mathrm{w} / \mathrm{o}$ emulsions. The $\mathrm{w} / \mathrm{o} / \mathrm{w}$ emulsion is then formed by the addition of second aqueous phase with continuous stirring. The solvent is removed from the emulsion by evaporation, and nanoparticles are separated by high-speed centrifugation [25]. Double emulsion technique is employed for encapsulation of hydrophilic drug [26].

\section{Salting out method}

Water-miscible solvent is separated from aqueous solution by means of a salting-out effect [27]. This method is of use for heat-sensitive substances, as it does not need an increase of temperature [28].

\section{Emulsions-diffusion method}

The encapsulating polymer is dissolved in a moderately water-miscible solvent and saturated with water. Then, the polymer-water saturated solvent phase is emulsified in stabilizer containing an aqueous solution. The solvent is eliminated by filtration or evaporation. The method does not need homogenization, has high reproducibility, and reduces scale up [29].

\section{Solvent precipitation method}

This method involves the preformed polymer precipitation from an organic solution and diffusion of the organic solvent in the aqueous medium in presence/absence of surfactants [30].

\section{Dialysis}

The proper molecular weight cutoff polymer is dissolved in an organic solvent and placed inside a dialysis tube. Dialysis is performed. The solvent displacement inside the membrane is followed by the 
polymer aggregation and formation of homogeneous nanoparticles suspension [31].

\section{Supercritical fluid technology}

Supercritical fluids are an environmentally friendly solvent and have the potential of producing polymer nanoparticles with high purity [32]. It offers an interesting and effective technique of particle production and avoids the drawbacks associated with the traditional methods [33].

\section{PREPARATION OF NANOPARTICLES BY MONOMER POLYMERIZATION (E.G., POLY [ISOBUTYL CYANOACRYLATES] [PICA], POLY [BUTYL CYANOACRYLATES] [PBCA], AND POLY HEXYL CYANOACRYLATES [PHCA])}

\section{Emulsion polymerization}

One of the first methods used for the production of nanoparticles has become less important due to the use of toxic organic solvents [34,35].

\section{Mini-emulsion polymerization}

Mini-emulsion polymerization uses low molecular mass compound as the costabilizer and a high-shear device (ultrasound) [36].

\section{Microemulsion polymerization}

The water-soluble initiator is added to the aqueous phase of thermodynamically stable swollen micelles containing microemulsion. The particles are completely covered with a surfactant which possesses an interfacial tension, close to zero at the oil/water interface [37].

\section{Interfacial polymerization}

It is a type of step-growth polymerization in which polymerization occurs at an interface between an aqueous solution containing one monomer and an organic solution containing a second monomer [38,39].

\section{PHYSICOCHEMICAL CHARACTERIZATION OF NANOPARTICLES}

The transfection efficiency of nanoparticles is characterized by their particle size, morphology, and surface charge, using sophisticated microscopic techniques as scanning electron microscopy, transmission electron microscopy, dynamic light scattering, and atomic force microscopy [40]. The physical stability and distribution of nanoparticles are affected by particle diameter, size distribution, and their surface charge [41-43].

\section{THERAPEUTIC APPLICATION OF NANOPARTICLES}

\section{For tumor-targeting drug delivery}

Nanoparticles form an ideal solution for the anticancer drugs with improved selectivity and reduced side-effects toward the tumor cells. Drug-loaded nanoparticles can be engineered to perform more complex, cooperative targeting functions [5,44]. Nanoparticle-based drug delivery systems overcome the pharmacokinetic limitations associated with conventional formulations. Nanoparticle causes targeted cell death by interfering with the overexpressed proteins proliferation [45]. Etoposide or paclitaxel lipid nanocapsules showed a 4- to 40-fold higher efficiency in a cancer cell culture as compared to the drug solution. The nanoparticulate system was also found to meet efficient intracellular drug concentrations [46]. Nanoparticles were found to be beneficial for the selective delivery of oligonucleotides to cancer cells. Nanoparticles also show the capacity to overcome multidrug resistance in chemotherapy [47]. Iron oxide nanoparticles were found to act as both magnetic and photothermal agents, which lead to complete apoptosis-mediated cell death. Magnetic mode treatment used singly reduced the tumor growth, treatment with both modes resulted in complete tumor regression [48]. Gold nanoparticles functionalized exclusively to interact with biomolecules of interest because of their smallness and ease of bioconjugation, and thus, have emerged as candidates for targeting cancer cells, at the same time displaying low cytotoxicity $[49,50]$. Silk fibroin-derived curcumin nanoparticles found to be highly effective against breast cancer due to their local, sustained, and long-term therapeutic delivery [51]. Polymeric micelles represent an effective delivery system for poorly water-soluble anticancer drugs due to their ability to show prolonged circulation time in the blood and enhanced tumor accumulation [52].

\section{For brain targeting drug delivery}

The blood-brain barrier (BBB) is a fundamental, unique, and protective boundary which control homeostasis, ion, and molecule movement between blood and neural tissue [53]. Its unique characteristics are its relatively impermeable endothelial cells with tight junctions, enzymatic activity, and active efflux transport systems [54]. Hence, the BBB gives serious challenges to drug delivery into the brain. The use of nanoparticles formulation can target specific transport processes, may enhance drug transport through the BBB, and can target relevant regions in the brain for regenerative processes [55]. The novel apolipoprotein E-functionalized nanoparticles system was created to enter the brain. The system acted by enhancing the binding to low-density lipoprotein receptors present on the BBB of endothelial cells. The system was found to be dynamically stable and capable of an improved and specialized delivery of drugs through the BBB [56]. It is now possible to synthesize brain-targeted pegylated immunonanoparticles using peptidomimetic antibodies to BBB transcytosis receptor. These make possible the delivery of active drug entrapped in the brain parenchyma without inducing permeability alteration of BBB [57].

\section{For oral drug delivery}

It is the most common method of drug administration with a higher level of patient acceptance. However still, it is linked with a number of barriers, such as acidic $\mathrm{pH}$ of the stomach and digestive enzymes [58]. The nanoparticle delivery in this system occurs by transcytosis and intracellular uptake, and transport occurs through the epithelial cells lining intestinal mucosa and Peyer's patches [59]. It was studied by Sharma et al., that wheat germ agglutinin coated lectin-functionalized poly nanoparticles could be used as potential drug carriers for antitubercular drugs through the oral as well as aerosol route [60]. Nanoparticles with peptide ligands can be used for specific targeting in the gastrointestinal tract [61]. VB12-dextran nanoparticle conjugate was found to be a viable carrier for oral insulin delivery in animal models of diabetes [62]. It was studied that nanoparticles offer a suitable method for oral delivery of water-insoluble drugs such as rapamycin. It was reviewed that polymeric nanoparticles prevent inactivation and degradation caused by acidic $\mathrm{pH}$ and digestive enzymes [57]. A nanoparticle adheres to the mucosa and thus enhances the absorption of the associated drug [63]. Neonatal Fc receptor present in the small intestine and colon is the target for nanoparticles [64]. It was concluded that FcRn-targeted nanoparticles may enable effective delivery of drugs whose action is limited by low bioavailability through oral administration [65].

\section{For transdermal drug delivery}

Topical or transdermal drug delivery is a challenge as the skin acts as a natural and protective barrier [66]. The protective function of the skin is attributed to the epidermal stratum corneum layer. This layer also regulates the transport of compounds into the skin [67]. The nanoparticles act as a reservoir of lipophilic drugs and deliver them to the stratum corneum. Polymeric nanoparticles increase the drug adhesivity and duration for skin permeation [68]. The gelatin pilocarpine hydrochloride $(\mathrm{HCl})$ or hydrocortisone nanoparticles produced using a desolations method showed sustained drug release compared to the aqueous solution of the drugs [69]. Vitamin A-loaded glyceryl behenate solid lipid nanoparticles showed increased drug release as compared to nanoemulsions. It was observed that polymorphic transitions and drug release were correlated [70].

\section{For parenteral drug delivery}

Parenteral formulations, mainly intravascular, offer a benefit of direct administration of the drug into the bloodstream and fast onset of drug action [71]. Further, it is also useful as passive drug delivery to inflammatory sites [72]. It was studied that miR-34a and siRNAs coformulated in GC4-targeted nanoparticles, when administered as 
Table 1: Method for preparation of nanoparticles: From preformed polymers (advantages and disadvantages)

\begin{tabular}{|c|c|c|c|c|}
\hline S.No. & Method & Advantages & Disadvantages & Formulations \\
\hline 1 & $\begin{array}{l}\text { Solvent evaporation } \\
\text { method }\end{array}$ & $\begin{array}{l}\text { Suitable thermolabile drugs } \\
\text { Small particle size around } 100 \mathrm{~nm} \\
\text { with narrow size distribution can } \\
\text { be achieved }\end{array}$ & $\begin{array}{l}\text { Presence of solvent residues in the final } \\
\text { dispersion may create problems } \\
\text { The partial solubility of lipids in organic } \\
\text { materials leads to dilute dispersions and } \\
\text { requires concentration by ultra-filtration, } \\
\text { evaporation, or lyophilization } \\
\text { Poor entrapment of hydrophilic drugs }\end{array}$ & $\begin{array}{l}\text { Ibuprofen loaded } \\
\text { Eudragit-S100 } \\
\text { nanoparticles [12] }\end{array}$ \\
\hline 2 & $\begin{array}{l}\text { Double emulsion } \\
\text { and evaporation } \\
\text { method }\end{array}$ & $\begin{array}{l}\text { Used for encapsulation of } \\
\text { hydrophilic drugs }\end{array}$ & $\begin{array}{l}\text { Characterization of nanoparticles is affected } \\
\text { by the amount of hydrophilic drug to be } \\
\text { incorporated, a concentration of stabilizer } \\
\text { used, polymer concentration, and the volume of } \\
\text { aqueous phase }\end{array}$ & $\begin{array}{l}\text { Daunorubicin-loaded } \\
\text { polymeric } \\
\text { nanoparticle [13] }\end{array}$ \\
\hline 3 & Salting out method & $\begin{array}{l}\text { Minimizes stress to protein } \\
\text { encapsulants } \\
\text { Does not require an increase in } \\
\text { temperature, and therefore, useful } \\
\text { for heat sensitive substances }\end{array}$ & $\begin{array}{l}\text { Exclusive application of lipophilic drugs } \\
\text { Extensive nanoparticle washing steps }\end{array}$ & $\begin{array}{l}\text { Isoniazid-loaded } \\
\text { nanoparticles [14] }\end{array}$ \\
\hline 4 & $\begin{array}{l}\text { Emulsions-diffusion } \\
\text { method }\end{array}$ & $\begin{array}{l}\text { High encapsulation } \\
\text { efficiencies }(>70 \%) \\
\text { Needs no homogenization } \\
\text { High batch to batch reproducibility } \\
\text { Ease of scale-up } \\
\text { Simple and narrow size } \\
\text { distribution }\end{array}$ & $\begin{array}{l}\text { High volumes of water to be eliminated from the } \\
\text { suspension } \\
\text { Leakage of the water-soluble drug into the } \\
\text { saturated-aqueous external phase during } \\
\text { emulsification } \\
\text { Reduced encapsulation efficiency }\end{array}$ & $\begin{array}{l}\text { Nanoparticles loaded } \\
\text { Neem oil [15] }\end{array}$ \\
\hline 5 & $\begin{array}{l}\text { Solvent } \\
\text { precipitation } \\
\text { method }\end{array}$ & $\begin{array}{l}\text { Simple and rapid preparation } \\
\text { Easy control of particle size and } \\
\text { composition } \\
\text { Suited for most of the poorly } \\
\text { soluble drugs }\end{array}$ & $\begin{array}{l}\text { Particle size is affected by rates of addition of the } \\
\text { organic phase into the aqueous phase }\end{array}$ & $\begin{array}{l}\text { Azithromycin } \\
\text { nanoparticles [16] }\end{array}$ \\
\hline 6 & Dialysis & Simple and effective method & $\begin{array}{l}\text { The solvent used in the preparation of the } \\
\text { polymer solution affects the morphology and } \\
\text { particle size distribution of the nanoparticles }\end{array}$ & $\begin{array}{l}\text { Vancomycin-loaded } \\
\text { N-trimethyl chitosan } \\
\text { nanoparticles [17] }\end{array}$ \\
\hline
\end{tabular}

Table 2: Method for preparation of nanoparticles: By monomer polymerization (advantages and disadvantages)

\begin{tabular}{|c|c|c|c|c|}
\hline S.No. & Method & Advantages & Disadvantages & Formulations \\
\hline 1 & $\begin{array}{l}\text { Emulsion } \\
\text { polymerization }\end{array}$ & $\begin{array}{l}\text { Fastest method } \\
\text { Readily scalable }\end{array}$ & $\begin{array}{l}\text { It requires toxic organic solvents, } \\
\text { surfactants, monomers, and } \\
\text { initiator, which are subsequently } \\
\text { eliminated from the formed } \\
\text { particles }\end{array}$ & Organic-inorganic nanocomposite particles [19] \\
\hline 2 & $\begin{array}{l}\text { Mini-emulsion } \\
\text { polymerization }\end{array}$ & $\begin{array}{l}\text { The typical formulation } \\
\text { used in mini-emulsion } \\
\text { polymerization consists of } \\
\text { water, monomer mixture, } \\
\text { co-stabilizer, surfactant, and } \\
\text { initiator }\end{array}$ & $\begin{array}{l}\text { Critically stabilized, require a } \\
\text { high-shear to reach a steady state }\end{array}$ & Hydrogels in miniemulsions [20] \\
\hline 3 & $\begin{array}{l}\text { Micro-emulsion } \\
\text { polymerization }\end{array}$ & $\begin{array}{l}\text { No specialized equipment } \\
\text { required } \\
\text { No energy required } \\
\text { Scale-up production possible }\end{array}$ & $\begin{array}{l}\text { Particle suspension diluted with } \\
\text { water, removal of excess water is } \\
\text { needed } \\
\text { Surfactants and co-surfactants } \\
\text { concentration is high in the } \\
\text { formulation, which has to be } \\
\text { removed using ultrafiltration, } \\
\text { ultracentrifugation, or dialysis }\end{array}$ & Organic and inorganic nanomaterials [21] \\
\hline 4 & $\begin{array}{l}\text { Interfacial } \\
\text { polymerization }\end{array}$ & Well-established methods & $\begin{array}{l}\text { The organic solvent, which is } \\
\text { completely miscible with water, } \\
\text { served as a monomer vehicle }\end{array}$ & Lomustine-loaded PLGA nanoparticles [22] \\
\hline
\end{tabular}


daily two intravenous injections showed an enhanced anticancer effect [73]. This technology by escalating the amount of drug reaching the target site improves drug delivery to macrophages, and thus, reduces therapeutic dose and adverse effects [74]. Nanocrystalline clofazimine was found to be equally effective when administered as liposomal clofazimine in reducing bacterial loads in the liver, spleen, and lungs of infected mice following i.v. administration [75]. The single subcutaneous dose of poly DL-lactide-co-glycolide nanoparticles of three front-line antitubercular drugs resulted in sustained therapeutic drug plasma levels in the lungs and spleen. The mean residence time and absolute bioavailability of drug were also found to be increased several times demonstrating a better chemotherapeutic efficacy [76].

\section{For pulmonary drug delivery}

The potential benefit of the direct delivery of the drug to the lungs is that it reduces systemic toxicity and higher drug concentration at the site of infection can be achieved [59]. The route offers a high surface area and rapid absorption because of high vascularization of the lungs, and another benefit is that it circumvents the first pass effect [77]. A possible obstacle for pulmonary nanocarriers is their small mass median aerodynamic diameter, an essential parameter for the particle deposition in the lungs [78]. Poly DL-lactide-co-glycolide nanoparticles of three frontline antitubercular drugs form a sound basis for improving drug bioavailability and reducing the dosing frequency for better management of pulmonary tuberculosis [79]. It was studied that pulmonary delivery of solid lipid nanoparticles of amikacin by microsprayer reduced its side effects in the kidneys and prolonged the dosing intervals due to the sustained drug release [80]. Gelatin and poly (lactic-co-glycolic) acid nanoparticles of plasmid DNA encoding a yellow fluorescent protein or rhodamine-conjugated erythropoietin for inhalational delivery enhances the duration of protein expression [81]. Biodegradable hydroxybenzyl alcohol-incorporated polyoxalate nanoparticles when studied as antiasthmatic agent remarkably reduced the recruitment of inflammatory cells and expression of pro-inflammatory mediators such as IL-4 and iNOS [82]. Formulation of paclitaxel-loaded poly (glycolide-co-e-caprolactone)-b-D- $\alpha$-tocopheryl polyethylene glycol 2000 succinate nanoparticles minimized the side effects of the drug and improved its therapeutic efficacy in lung chemotherapy [83]. Chitosan and glycol chitosan nanoparticles of low molecular weight heparin were evaluated for the systemic delivery after pulmonary administration, and the results illustrated promising features [84].

\section{For ocular drug delivery}

Ocular drug transport barriers possess the challenge because of the tear film, blood-aqueous barrier, and blood-retinal barrier [85]. Nanoparticles have the advantage that they show improved topical passage of large, poorly water-soluble molecules such as glucocorticoid and cyclosporine, and are useful in immune-related and visionthreatening diseases [86]. When combined with controlled drug delivery, they reduce the drug dose and administration frequency. They also decrease side effects and help in the site-specific targeting of the drug [87]. Drug-loaded polymeric nanoparticles offer several favorable biological properties such as biodegradability, nontoxicity, biocompatibility, and mucoadhesiveness [88]. Cyclosporine A nanoparticles, when used for the treatment of eye inflammation, was proved to be a useful approach because of improved ocular retention and bioavailability [89]. Brimonidine tartrate-loaded chitosan nanoparticles showed sustained release and confirmed a significant sustained effect as compared to conventional eye drops [90]. It was found that positively-charged pilocarpine $\mathrm{HCl}$-loaded polymeric and lipid nanoparticles were prepared successfully and had potential use for ophthalmic delivery [91]. It was studied that comparison to free drug solution, nanostructured lipid carriers formed by incorporation of liquid oil in the structure of solid lipid nanoparticles were more capable of faster permeation through the excised cornea [92].

\section{For intranasal drug delivery}

Oral, parenteral, rectal, and other routes of drug administration are associated with a number of problems, which increased the interest of pharmaceutical scientists toward exploring the possibilities of intranasal drug delivery [93]. The drug delivered by the intranasal route bypasses the BBB. Nanoparticles are taken up by olfactory neurons and conveyed along cell processes to synaptic junctions with neurons of the olfactory bulb [94]. Neurological conditions that could benefit from nose-to-brain delivery of nanotherapeutics are the pain, epilepsy, neurodegenerative disease, and infectious diseases [95]. The rivastigmine-loaded chitosan nanoparticles were found to have better brain targeting efficiency and were considered a promising approach for intranasal delivery for the treatment and prevention of Alzheimer's disease [96]. Bromocriptine-loaded chitosan nanoparticles studied as a delivery system to enhance the brain targeting efficiency following intranasal administration were found to have improved drug targeting index and direct transport percentage [97].

\section{CONCLUSION}

Nanoparticles have been shown to have varied prospective applications in pharmaceutics. They have been found to be beneficial in diagnosis, treatment, and surgeries. Nanoparticles improve the stability of drug inside the body by protecting the drug molecule inside systemic circulation. They also confine access of the drug to a specific site at a controlled and sustained rate. The main concern of future research can be done in preparation of nanoparticles which can further withstand the biological diversities and thus further improve drug stability in the biological environment and hence its bioavailability.

\section{REFERENCES}

1. Hasan S. A review on nanoparticles: Their synthesis and types. Res J Recent Sci 2015;4:1-3.

2. Klaus T, Joerger R, Olsson E, Granqvist CG. Silver-based crystalline nanoparticles, microbially fabricated. J Proc Natl Acad Sci USA 1999;96:13611-4.

3. Zare-Zardini H, Amiri A, Shanbedi M, Taheri-Kafrani A, Sadri Z, Ghanizadeh F, et al. Nanotechnology and pediatric cancer: Prevention, diagnosis and treatment. Iran J Ped Hematol Oncol 2015;5:233-48.

4. Zhang L, Gu FX, Chan JM, Wang AZ, Langer RS, Farokhzad OC. Nanoparticles in medicine: Therapeutic applications and developments. Clin Pharmacol Ther 2008;83:761-9.

5. Banyal S, Malik P, Tuli HS, Mukherjee TK. Advances in nanotechnology for diagnosis and treatment of tuberculosis. Curr Opin Pulm Med 2013;19:289-97.

6. Zhang L, Pornpattananangku D, Hu CM, Huang CM. Development of nanoparticles for antimicrobial drug delivery. Curr Med Chem 2010;17:585-94

7. Singh S, Pandey VK, Tewari PR, Agarwal V. Nanoparticle based drug delivery system: Advantages and applications. Indian J Sci Technol 2011;4:177-80

8. Saija HK, East MP, Mao H, Wang YA, Nie S, Yang L. Development of multifunctional nanoparticles for targeted drug delivery and noninvasive imaging of therapeutic effect. Curr Drug Discov Technol 2009;6:43-51.

9. Nagavarma BV, Yadav KS, Ayaz A, Vasudha LS, Shivakumar HG. Different techniques for preparation of polymeric nanoparticles-a review. Asian J Pharm Clin Res 2012;5:16-23.

10. Abhilash M. Potential applications of nanoparticles. Int J Pharm Bio Sci 2010;1:1-12.

11. Vineela CH, Sailaja KK. Preparation of ibuprofen-loaded eudragit S100 nanoparticles by the solvent evaporation technique. Int J Pharm Sci Res 2014;5:375-84.

12. Liu J, Qiu Z, Wang S, Zhou L, Zhang S. A modified double-emulsion method for the preparation of daunorubicin-loaded polymeric nanoparticle with enhanced in vitro anti-tumor activity. Biomed Mater 2010;5:065002.

13. du Toit LC, Pillay V, Choonara YE, Iyuke SE. Formulation and evaluation of a salted-out isoniazid-loaded nanosystem. AAPS PharmSciTech 2008;9:174-81

14. Vijayan V, Aafreen S, Sakthivel S, Reddy KR. Formulation and characterization of solid lipid nanoparticles loaded neem oil for topical treatment of acne. J Acute Dis 2013;2:282-6.

15. Pouretedal HR. Preparation and characterization of azithromycin nano drug using solvent/anti-solvent method. Int Nano Lett 2014;4:103.

16. Xu J, Xu B, Shou D, Xia X, Hu Y. Preparation and evaluation of 
vancomycin-loaded N-trimethyl chitosan nanoparticles. Polymers 2015;7:1850-70.

17. Akbari Z, Amanlou M, Karimi-Sabet J, Golestani A, Niasar MS. Haracterization of carbamazepine-loaded solid lipid nanoparticles prepared by rapid expansion of supercritical solution. Trop J Pharm Res 2014;13:1955-61.

18. Ma H, Luo M, Sanyal S, Rege K, Dai LK. The one-step Pickering emulsion polymerization route for synthesizing organic-inorganic nanocomposite particles. Materials 2010;3:1186-202.

19. Landfester K, Musyanovych A. Hydrogels in miniemulsions. Adv Polym Sci 2010;234:39-63

20. Malik MA, Wani MY, Hashim MA. Microemulsion method: A novel route to synthesize organic and inorganic nanomaterials: $1^{\text {st }}$ nano update. Arab J Chem 2012;5:397-417.

21. Mehrotra A, Pandit JK. Preparation and characterization and biodistribution studies of lomustine loaded PLGA nanoparticles by interfacial deposition method. J Nanomed Biother Discov 2015;5:1-10.

22. Balasubramanian J, Narayan N, Pragadeesh K. Biodegradable PEG nanoparticles for colorectal cancer using irinotecan as anticancer agent. Int J Pharm Pharm Sci 2014;6:50-4.

23. Amirah MG, Amirul AA, Wahab HA. Formulation and characterization of rifampicin-loaded $\mathrm{P}(3 \mathrm{HB}-\mathrm{co}-4 \mathrm{HB})$ nanoparticles. Int J Pharm Pharm Sci 2014;6:140-6.

24. Vandervoort J, Ludwig A. Biocompatible stabilizers in the preparation of PLGA nanoparticles: A factorial design study. Int $\mathrm{J}$ Pharm 2002;238:77-92.

25. Ubrich N, Bouillot P, Pellerin C, Hoffman M, Maincent P. Preparation and characterization of propranolol hydrochloride nanoparticles: A comparative study. J Control Release 2004;97:291-300.

26. Catarina PR, Ronald JN, Antonio JR. Nano capsulation 1 method of preparation of drug-loaded polymeric nanoparticles. Nanotech Biol Med 2006;2:8-21.

27. Lambert G, Fattal E, Couvreur P. Nanoparticulate systems for the delivery of antisense oligonucleotides. Adv Drug Deliv Rev 2001;47:99-112.

28. Takeuchi H, Yamamoto Y. Mucoadhesive nanoparticulate system for peptide drug delivery. Adv Drug Deliv Rev 2001;47:39-54.

29. Chorny M, Fishbein I, Danenberg HD, Golomb G. Lipophilic drug loaded nanospheres prepared by nanoprecipitation: Effect of formulation variables on size, drug recovery and release kinetics. J Control Release 2002;83:389-400.

30. Fessi H, Puisieux F, Devissaguet JP, Ammoury N. Nanocapsule formation by interfacial deposition following solvent displacement. Int J Pharm 1989;55:R1-4.

31. York P. Strategies for particle design using supercritical fluid technologies. Pharm Sci Technolo Today 1999;2:430-40.

32. Kawashima Y. Panoparticulate systems for improved drug delivery. Adv Drug Deliv Rev 2001;47:1-2.

33. Ekman B, Sjöholm I. Improved stability of proteins immobilized in microparticles prepared by a modified emulsion polymerization technique. J Pharm Sci 1978;67:693-6.

34. Lowe PJ, Temple CS. Calcitonin and insulin in isobutylcyanoacrylate nanocapsules: Protection against proteases and effect on intestinal absorption in rats. J Pharm Pharmacol 1994;46:547-52.

35. Prasad RJ, Geckeler KE. Polymer nanoparticles: Preparation techniques and size control parameters. Prog Polym Sci 2011;36:887-913.

36. Puig JE. Microemulsion polymerization (oil-in water). Polym Mater Encyclopedia 1996;94:4333-41.

37. Gallardo M, Couarraze G, Denizot B, Treupel L, Couvreur P, Puisieux F. Study of the mechanisms of formation of nanoparticles and nanocapsules of poly(isobutyl-2-cyanoacrylate). Int J Pharm 1993;100:55-64

38. Aboubakar M, Puisieux F, Couvreur P, Deyme M, Vauthier C. Study of the mechanism of insulin encapsulation in poly(isobutylcyanoacrylate) nanocapsules obtained by interfacial polymerization. J Biomed Mater Res 1999;47:568-76.

39. Nimesh S. 3-tools and techniques for physico-chemical characterization of nanoparticles. Gene Ther 2013;43-63.

40. Pal LS, Jana U, Manna PK, Mohanta GP, Manavalan R. Nanoparticle: An overview of preparation and characterization. J Appl Pharm Sci 2011;1:228-34

41. Redhead HM, Davis SS, Illum L. Drug delivery in poly(lactide-coglycolide) nanoparticles surface modified with poloxamer 407 and poloxamine 908: In vitro characterisation and in vivo evaluation. J Control Release 2001;70:353-63.

42. Pangi Z, Beletsi A, Evangelatos K. PEG-ylated nanoparticles for biological and pharmaceutical application. Adv Drug Deliv Rev
2003;24:403-19.

43. Ruoslahti E, Bhatia SN, Sailor MJ. Targeting of drugs and nanoparticles to tumors. J Cell Biol 2010;188:759-68.

44. Huynh NT, Passirani C, Saulnier P, Benoit JP. Lipid nanocapsules: A new platform for nanomedicine. Int J Pharm 2009;379:201-9.

45. Heuer-Jungemann A, El-Sagheer AH, Lackie PM, Brown T, Kanaras AG. Selective killing of cells triggered by their mRNA signature in the presence of smart nanoparticles. Nanoscale 2016;8:16857-61.

46. Lacoeuille F, Garcion E, Benoit JP, Lamprecht A. Lipid nanocapsules for intracellular drug delivery of anticancer drugs. J Nanosci Nanotechnol 2007; 7:4612-7.

47. Brigger I, Dubernet C, Couvreur P. Nanoparticles in cancer therapy and diagnosis. Adv Drug Deliv Rev 2002;54:631-51.

48. Espinosa A, Di Corato R, Kolosnjaj-Tabi J, Flaud P, Pellegrino T, Wilhelm C. Duality of iron oxide nanoparticles in cancer therapy: Amplification of heating efficiency by magnetic hyperthermia and photothermal bimodal treatment. ACS Nano 2016;10:2436-46.

49. Huang X, Jain PK, El-Sayed IH, El-Sayed MA. Gold nanoparticles: Interesting optical properties and recent applications in cancer diagnostics and therapy. Nanomedicine (Lond) 2007;2:681-93.

50. Kyriazi ME, Jungemann AH, Kanaras AG. How can nano-delivery systems selectively kill cancerous cells? Ther Deliv 2017;4:171-3.

51. Gupta V, Aseh A, Ríos CN, Aggarwal BB, Mathur AB. Fabrication and characterization of silk fibroin-derived curcumin nanoparticles for cancer therapy. Int J Nanomedicine 2009;4:115-22.

52. Zhang Y, Huang Y, Li S. Polymeric micelles: Nanocarriers for cancertargeted drug delivery. AAPS PharmSciTech 2014;15:862-71.

53. Mohanraj VJ, Chen Y. Nanoparticles-a review. Trop J Pharm Res 2006;5:561-73.

54. Chen Y, Dalwadi G, Benson HA. Drug delivery across the blood-brain barrier. Curr Drug Deliv 2004;1:361-76.

55. Saraiva C, Praça C, Ferreira R, Santos T, Ferreira L, Bernardino L. Nanoparticle-mediated brain drug delivery: Overcoming bloodbrain barrier to treat neurodegenerative diseases. J Control Release 2016;235:34-47.

56. Neves AR, Queiroz JF, Weksler B, Romero IA, Couraud PO, Reis S. Solid lipid nanoparticles as a vehicle for brain-targeted drug delivery: Two new strategies of functionalization with apolipoprotein E. Nanotechnology 2015;26:495103.

57. Olivier JC. Drug transport to brain with targeted nanoparticles. NeuroRx 2005;2:108-19.

58. Pridgen EM, Alexis F, Farokhzad OC. Polymeric nanoparticle technologies for oral drug delivery. Clin Gastroenterol Hepatol 2014; $12: 1605-10$.

59. Gelperina S, Kisich K, Iseman MD, Heifets L. The potential advantages of nanoparticle drug delivery systems in chemotherapy of tuberculosis. Am J Respir Crit Care Med 2005;172:1487-90.

60. Sharma A, Sharma S, Khuller GK. Lectin-functionalized poly (lactide-co-glycolide) nanoparticles as oral/aerosolized antitubercular drug carriers for treatment of tuberculosis. J Antimicrob Chemother 2004;54:761-6.

61. Yun Y, Cho YW, Park K. Nanoparticles for oral delivery: Targeted nanoparticles with peptidic ligands for oral protein delivery. Adv Drug Deliv Rev 2013;65:822-32.

62. Chen MC, Sonaje K, Chen KJ, Sung HW. A review of the prospects for polymeric nanoparticle platforms in oral insulin delivery. Biomaterials 2011;32:9826-38.

63. Bisht S, Feldmann G, Koorstra JB, Mullendore M, Alvarez $\mathrm{H}$, Karikari $\mathrm{C}$, et al. In vivo characterization of a polymeric nanoparticle platform with potential oral drug delivery capabilities. Mol Cancer Ther 2008:7:3878-88.

64. Yoshida M, Claypool SM, Wagner JS, Mizoguchi E, Mizoguchi A, Roopenian DC, et al. Human neonatal Fc receptor mediates transport of $\mathrm{IgG}$ into luminal secretions for delivery of antigens to mucosal dendritic cells. Immunity 2004;20:769-83.

65. Pridgen EM, Alexis F, Kuo TT, Levy-Nissenbaum E, Karnik R, Blumberg RS, et al. Transepithelial transport of Fc-targeted nanoparticles by the neonatal fc receptor for oral delivery. Sci Transl Med 2013:5:213ra167.

66. Desai P, Patlolla RR, Singh M. Interaction of nanoparticles and cellpenetrating peptides with skin for transdermal drug delivery. Mol Membr Biol 2010;27:247-59.

67. Zhang Z, Tsai PC, Ramezanli T, Michniak-Kohn BB. Polymeric nanoparticles-based topical delivery systems for the treatment of dermatological diseases. Wiley Interdiscip Rev Nanomed Nanobiotechnol 2013;5:205-18.

68. Guterres SS, Alves MP, Pohlmann AR. Polymeric nanoparticles, 
nanospheres and nanocapsules, for cutaneous applications. Drug Target Insights 2007;2:147-57.

69. Vandervoort J, Ludwig A. Preparation and evaluation of drug-loaded gelatin nanoparticles for topical ophthalmic use. Eur J Pharm Biopharm 2004;57:251-61.

70. Jenning V, Schäfer-Korting M, Gohla S. Vitamin A-loaded solid lipid nanoparticles for topical use: Drug release properties. J Control Release 2000;66:115-26.

71. Constantinides PP, Chaubal MV, Shorr R. Advances in lipid nanodispersions for parenteral drug delivery and targeting. Adv Drug Deliv Rev 2008;60:757-67.

72. Moghimi SM, Hunter AC, Murray JC. Long-circulating and target-specific nanoparticles: Theory to practice. Pharmacol Rev 2001;53:283-318

73. Chen Y, Zhu X, Zhang X, Liu B, Huang L. Nanoparticles modified with tumor-targeting scFv deliver siRNA and miRNA for cancer therapy. Mol Ther 2010;18:1650-6.

74. Kayser O, Olbrich C, Croft SL, Kiderlen AF. Formulation and biopharmaceutical issues in the development of drug delivery systems for antiparasitic drugs. Parasitol Res 2003;90 Suppl 2:S63-70.

75. Peters K, Leitzke S, Diederichs JE, Borner K, Hahn H, Müller RH, et al. Preparation of a clofazimine nanosuspension for intravenous use and evaluation of its therapeutic efficacy in murine Mycobacterium avium infection. J Antimicrob Chemother 2000;45:77-83.

76. Pandey R, Khuller GK. Subcutaneous nanoparticle-based antitubercular chemotherapy in an experimental model. J Antimicrob Chemother 2004;54:266-8

77. Paranjpe M, Müller-Goymann CC. Nanoparticle-mediated pulmonary drug delivery: A review. Int J Mol Sci 2014;15:5852-73.

78. Junise V, Saraswathi R. Development and characterization of inhaled chitosan nanoparticles loaded with isoniazid. J Pharmal Technol Res Manage 2014;2:159-70.

79. Pandey R, Sharma A, Zahoor A, Sharma S, Khuller GK, Prasad B, et al. Poly (DL-lactide-co-glycolide) nanoparticle-based inhalable sustained drug delivery system for experimental tuberculosis. J Antimicrob Chemother 2003;52:981-6.

80. Varshosaz J, Ghaffari S, Mirshojaei SF, Jafarian A, Atyabi F, Kobarfard F, et al. Biodistribution of amikacin solid lipid nanoparticles after pulmonary delivery. Biomed Res Int 2013;2013:136859.

81. Menon JU, Ravikumar P, Pise A, Gyawali D, Hsia CC, Nguyen KT. Polymeric nanoparticles for pulmonary protein and DNA delivery. Acta Biomater 2014;10:2643-52.

82. Yoo D, Guk K, Kim H, Khang G, Wu D, Lee D. Antioxidant polymeric nanoparticles as novel therapeutics for airway inflammatory diseases. Int J Pharm 2013;450:87-94.
83. Zhao $\mathrm{T}$, Chen $\mathrm{H}$, Dong $\mathrm{Y}$, Zhang J, Huang $\mathrm{H}$, Zhu J, et al. Paclitaxel-loaded poly(glycolide-co-e-caprolactone)-b-D-a-tocopheryl polyethylene glycol 2000 succinate nanoparticles for lung cancer therapy. Int J Nanomedicine 2013;8:1947-57.

84. Trapani A, Di Gioia S, Ditaranto N, Cioffi N, Goycoolea FM, Carbone A, et al. Systemic heparin delivery by the pulmonary route using chitosan and glycol chitosan nanoparticles. Int J Pharm 2013;447:115-23.

85. Zhou HY, Hao JL, Wang S, Zheng Y, Zhang WS. Nanoparticles in the ocular drug delivery. Int J Ophthalmol 2013;6:390-6.

86. Diebold Y, Calonge M. Applications of nanoparticles in ophthalmology. Prog Retin Eye Res 2010;29:596-609.

87. Vandervoort J, Ludwig A. Ocular drug delivery: Nanomedicine applications. Nanomedicine (Lond) 2007;2:11-21

88. Nagarwal RC, Kant S, Singh PN, Maiti P, Pandit JK. Polymeric nanoparticulate system: A potential approach for ocular drug delivery. J Control Release 2009;136:2-13.

89. Aksungur P, Demirbilek M, Denkbas EB, Vandervoort J, Ludwig A, Unlü N. Development and characterization of cyclosporine a loaded nanoparticles for ocular drug delivery: Cellular toxicity, uptake, and kinetic studies. J Control Release 2011;151:286-94.

90. Singh KH, Shinde UA. Chitosan nanoparticles for controlled delivery of brimonidine tartrate to the ocular membrane. Pharmazie 2011;66:594-9.

91. Lütfi G, Müzeyyen D. Preparation and characterization of polymeric and lipid nanoparticles of pilocarpine $\mathrm{HCl}$ for ocular application. Pharm Dev Technol 2013;18:701-9.

92. Seyfoddin A, A1-Kassas R. Development of solid lipid nanoparticles and nanostructured lipid carriers for improving ocular delivery of acyclovir. Drug Dev Ind Pharm 2013;39:508-19.

93. Kang ML, Cho CS, Yoo HS. Application of chitosan microspheres for nasal delivery of vaccines. Biotechnol Adv 2009;27:857-65.

94. Ali J, Ali M, Baboota S, Sahani JK, Ramassamy C, Dao L, et al. Potential of nanoparticulate drug delivery systems by intranasal administration. Curr Pharm Des 2010;16:1644-53.

95. Ong WY, Shalini SM, Costantino L. Nose-to-brain drug delivery by nanoparticles in the treatment of neurological disorders. Curr Med Chem 2014;21:4247-56.

96. Fazil M, Md S, Haque S, Kumar M, Baboota S. Development and evaluation of rivastigmine loaded chitosan nanoparticles for brain targeting. Eur J Pharm Sci 2012;47:6-15.

97. Md S, Khan RA, Mustafa G, Chuttani K, Baboota S, Sahni JK, et al. Bromocriptine loaded chitosan nanoparticles intended for direct nose to brain delivery: Pharmacodynamic, pharmacokinetic and scintigraphy study in mice model. Eur J Pharm Sci 2012;48:393-405. 